\title{
Ecological trap in the buffer zone of a protected area: effects of indirect anthropogenic mortality on the African wild dog Lycaon pictus
}

\author{
Esther van der Meer, Hervé Fritz, Peter Blinston \\ and GREGORY S.A. RASMUSSEN
}

\begin{abstract}
Because of the large home range requirements of wide-ranging carnivores, protected areas are often too small to maintain large populations. Consequently these carnivores regularly move outside protected areas, where they are likely to be exposed to anthropogenic mortality. We used data from 15 packs of radio-collared African wild dogs Lycaon pictus to examine the level of anthropogenic mortality African wild dogs experience around Hwange National Park, Zimbabwe, and tried to determine whether the buffer zone outside the Park acts as an 'ecological trap'. Over time, study packs moved their territories closer to or beyond the Park border. With the movement of territories into the buffer zone outside the Park, African wild dogs experienced an increasing level of anthropogenic mortality. Although larger litters were born outside the Park, mortality exceeded natality. Densities of the African wild dog in the study area were low and territories for given pack sizes were smaller outside the Park. Hence, the movement of packs outside the Park does not appear to be density related and the buffer zone is therefore unlikely to function as a classic sink. Favourable ecological conditions indicate that the buffer zone outside the Park is likely to serve as an ecological trap, with fitness-enhancing factors attracting African wild dogs outside the Park, where they are incapable of perceiving the higher mortality risk associated with mostly indirect anthropogenic causes. As far as we know this is one of the first studies describing an ecological trap for mammals.
\end{abstract}

Keywords African wild dog, anthropogenic mortality, ecological trap, habitat selection, Lycaon pictus, protected area, sink, vacuum effect

ESTHER VAN DER MEER* (Corresponding author) PETER BLINSTON and GREgory S A. Rasmussen Painted Dog Conservation, Hwange National Park, P.O. Box 72 Dete, Zimbabwe. E-mail: esther@cheetahzimbabwe.org

Hervé Fritz CNRS HERD Project, Hwange National Park, Dete, Zimbabwe, and Université de Lyon, CNRS Université Claude Bernard Lyon, Villeurbanne, France

* Also at: Laboratoire Biométrie et Biologie Evolutive, Université de Lyon, CNRS Université Claude Bernard Lyon, Villeurbanne, France

Received 7 April 2012. Revision requested 13 August 2012.

Accepted 10 October 2012. First published online 2 August 2013.

\section{Introduction}

A increase in the human population worldwide has resulted in fragmentation of habitat available to wildlife, thus forcing animals to live in close proximity to humans (Woodroffe, 2000; Inskip \& Zimmermann, 2009). Protected areas are often too small to maintain large populations of wildlife, and wide ranging carnivores, in particular, regularly roam beyond reserve borders (Woodroffe et al., 1997; Woodroffe \& Ginsberg, 1998). By crossing into unprotected areas animals are often accidentally or deliberately killed by humans (anthropogenic mortality; Woodroffe \& Ginsberg, 1998; Loveridge et al., 2007; Balme et al., 2009; Gusset et al., 2009; Inskip \& Zimmermann, 2009). As a result, border areas of reserves have the potential to become population sinks where mortality exceeds natality (Woodroffe \& Ginsberg, 1998).

The detrimental effect of these sinks can be accelerated by a vacuum effect, whereby removal of territorial individuals in the border areas results in vacant territories being filled by individuals from within the protected area that are attracted to these vacant territories by reduced levels of competition for resources (e.g. food, den sites, mates) (Loveridge et al., 2009a). For example, trophy hunting along the boundary of Hwange National Park created territorial vacuums that were filled by immigration of male lions Panthera leo from the Park core area in search of better mating opportunities (Loveridge et al., 2007, 2009a). Variations on this vacuum effect have been described for several other mammal species (Bailey et al., 1986; Ji et al., 2001; Gunther \& Terkel, 2002; Macdonald et al., 2006).

In a classic source-sink system, habitat choice is advantageous; animals choose to be in source habitat (natality $>$ mortality) and will only move into sink habitat (natality $<$ mortality) when there is insufficient source habitat available (Pulliam, 1988). Sometimes animals show a preferential choice for sink habitat in which reproductive success or adult survival is less than in other available habitat, in that case animals are caught in an ecological trap (Kokko \& Sutherland, 2001; Schlaepfer et al., 2002; Battin, 2004; Robertson \& Hutto, 2006). In an ecological trap, habitat choice is disadvantageous; animals choose to move into the sink habitat despite there being enough source habitat available (Kristan, 2003; Battin, 2004). Hence, in an ecological trap, the sink population can only be temporarily 


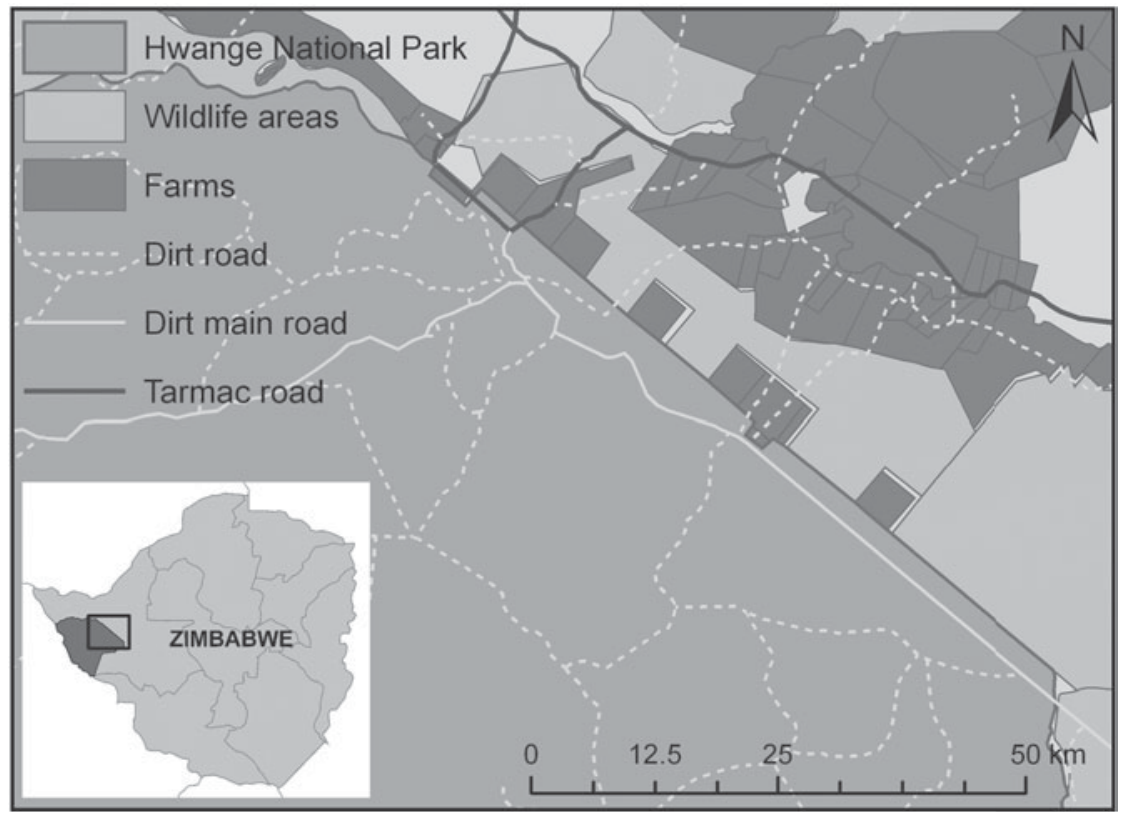

FIG. 1 The study area along the northern boundary of Hwange National Park, showing the protected wildlife area without human settlements (Hwange National Park), and the unprotected buffer zone with human settlements, designated for trophy hunting and photographic safaris (wildlife areas, farms). The rectangle on the inset indicates the position of the main map in Zimbabwe. sustained by the source population before resulting in an overall population decline (Kristan, 2003). Although ecological traps have been described for birds and insects, few studies have described ecological traps for mammals (Schlaepfer et al., 2002; Robertson \& Hutto, 2006).

Anthropogenic mortality around reserves has contributed to a rapid population decline of the African wild dog Lycaon pictus (Woodroffe et al., 1997; Woodroffe \& Ginsberg, 1998; Gusset et al., 2009), which is categorized as Endangered on the IUCN Red List (Woodroffe \& SilleroZubiri, 2012). This decline is accelerated by the species' sociality; African wild dogs hunt and breed cooperatively, which has resulted in a positive relationship between aspects of fitness and pack size (Courchamp \& Macdonald, 2001; Rasmussen et al., 2008; Gusset \& Macdonald 2010).

Hwange National Park is the largest protected wildlife area in Zimbabwe (Peace Parks Foundation, 2009). As in other parts of Africa, the African wild dog population in and around the Park has decreased dramatically. In 1997 it was estimated there were 150-225 African wild dogs in this area (Rasmussen, 1997; Woodroffe et al., 2004). Currently, the population in and around the Park is believed to be $50-70$ individuals (Zimbabwe Parks \& Wildlife Management Authority, 2009; Blinston et al., 2010). In this study we examined the reasons for this decline. We examined causes of mortality in and around the Park, the effect of territory placement on recruitment, and whether the buffer zone outside the Park functions as an ecological trap.

\section{Study area}

The c. 15,000 $\mathrm{km}^{2}$ Hwange National Park lies in north-west Zimbabwe. The Hwange region is classified as semi-arid, with a mean annual rainfall of $606 \mathrm{~mm}$, and a wet season from October to April. Vegetation comprises scattered woodland scrub, mixed with grassland. African wild dog prey species include impala Aepyceros melampus, kudu Tragelaphus strepsiceros and duiker Sylvicapra grimmia. Lions and spotted hyaenas Crocuta crocuta, the natural competitors of African wild dogs (Mills \& Gorman, 1997; Creel, 2001), occur in the study area. Data were collected along the northern boundary of the Park, in an area of 6,00o $\mathrm{km}^{2}$ that includes part of the Park and its peripheral area (Fig. 1). Hwange National Park is a protected wildlife area, within which there are no human settlements or main roads. The Park is managed to minimize human impact and prevent illegal activities such as poaching. The buffer zone is designated for trophy hunting and to a lesser extent for photographic safaris. Most of this land is privately owned or state owned, and there are several human settlements within the buffer zone. The main tarmac road from Bulawayo to Victoria Falls runs through part of the study area (Fig. 1). As a consequence of the type of land use, the infrastructure, and a high human density, anthropogenic mortality of wildlife has historically been high in the buffer zone surrounding the Park (Rasmussen, 1997; Loveridge et al., 2007).

\section{Methods}

\section{Data collection}

Data were collected by G.S.A.R, using radio tracking and opportunistic observations (e.g. sightings from tourists and hunters). Individual African wild dogs were identified using their unique coat markings. Data from 15 radio-collared African wild dog packs were used, collected between 1991 
and 2002, with a mean study duration of $29.5 \pm$ SD 20.1 months per pack. A pack was defined as a potential breeding unit containing at least an alpha male and an alpha female. Social status was determined by direct behavioural observations. As soon as a pack had been located it was monitored continuously, from a distance of $\geqslant 50 \mathrm{~m}$, for as long as practically feasible (maximum 28 days). Activity was monitored visually or from motion sensors incorporated in the radio collars. Activity patterns were recorded at 5-minute scan intervals. Whenever a change in activity mode or direction occurred, location fixes were taken by using triangulation or visual observations and a global positioning system.

Packs were followed for a maximum of 5 successive years during which pack sizes, litter sizes, immigration, dispersals and deaths were recorded. Pups were counted at the den site as soon as possible after emergence from the den. Records of mortality are based on cases for which the cause of death was undisputed, with a carcass as evidence, and on reports with strong circumstantial evidence (e.g. reports of a dog shot coinciding with a dog missing from a study pack known to be utilizing that area). For an overview of African wild dog mortality over time, the data from the known individual packs as well as data based on sightings and reports between 1989 and 2010 were used (some of these data were published previously in Woodroffe et al., 2007).

In and around Hwange National Park African wild dog pups are born in May-June. Hence, annual periods were defined as starting with the denning season in May-June and ending just before the denning season of the following year. Age of individual African wild dogs was classified as: adult, $\geqslant 2$ years old; yearling, $\geqslant 1$ year and $<2$ years old; pup, $<1$ year old.

\section{Analysis of data from study packs}

For each pack position data for a given year were plotted using ArcGis v. 9.3 (ESRI, Redlands, USA). The Home Range Tools v. 1.1 extension for ArcGis (Rodgers et al., 2007) was used to calculate territory sizes and draw isopleths. To avoid bias an average position per day was used and only packs with $>50$ points per year and $\geqslant 1$ point per week were included in the analysis. A 95\% fixed Kernel method using least square cross validation (Seaman \& Powell, 1996) was used to determine territory sizes inside and outside Hwange National Park. A 50\% fixed Kernel method using least square cross validation was used to calculate core areas inside and outside the Park (Janmaat et al., 2009; Tolon et al., 2009).

Based on the method used by Janmaat et al. (2009) and Tolon et al. (2009), centroids for each territory were determined by calculating the average of the $\mathrm{X}$ and $\mathrm{Y}$ coordinates of the position data for a given pack in a given year. For each year, distance of the territory centroids to the Park border was determined. Distances inside the Park were marked as positive values and distances outside the Park as negative values (Tolon et al., 2009). Thus a gradient was created, with a decrease in distance the further a pack moved outside the Park. For different packs data were collected over several years and therefore a new variable was created by numbering sequential years. Data were available for a maximum of 5 sequential years.

A linear mixed model, based on maximum likelihoods, was used to analyse whether over succeeding years the distance of the territory centroids to the Park border became smaller. To control for possible pseudo-replication because of the fact that some packs were followed over more sequential years than others, we added individual pack identity as a random variable in the analysis. A similar model was used to determine whether there was a relationship between pack size and distance of the centroid to the Park border. To analyse whether there was a relationship between the number of pups born in a litter and the distance of the territory centroid to the Park border, a linear mixed model was used with the variables pack size and distance to the border, including pack identity as a random variable. A similar model was used to analyse whether there was a relationship between the distance of the territory centroid to the Park border and dispersal and immigration within a pack. To determine the relationship between mortality and the distance of the territory centroids to the Park border, the relative mortality was calculated by dividing the number of individuals that died by the number of living individuals. This calculation was made for overall mortality, overall mortality known to have been caused by humans (e.g. snares, cars, animals being shot), direct mortality known to have been caused by humans (e.g. animals being shot), indirect mortality known to have been caused by humans (e.g. snares, cars), mortality known to have been caused by natural circumstances (e.g. lions, hyaenas, disease, old age), and mortality caused by unknown circumstances.

To meet the assumption of normality, all mortality proportions were arcsine square root transformed. For the analysis of overall, human-caused (overall, direct and indirect), natural, and unknown mortality, a linear mixed model was used with distance of the territory centroid to the Park border as a variable and pack identity as a random variable. A similar model was used to determine whether the distance of the territory centroid to the border affected the size of territories and core areas used by the study packs. A $t$-test was used to compare the mean territory and core area size for packs with territory centroids inside and outside the Park.

As the position of the centroid of an African wild dog territory does not necessarily show whether the territory covers land strictly inside, both inside and outside, or strictly 

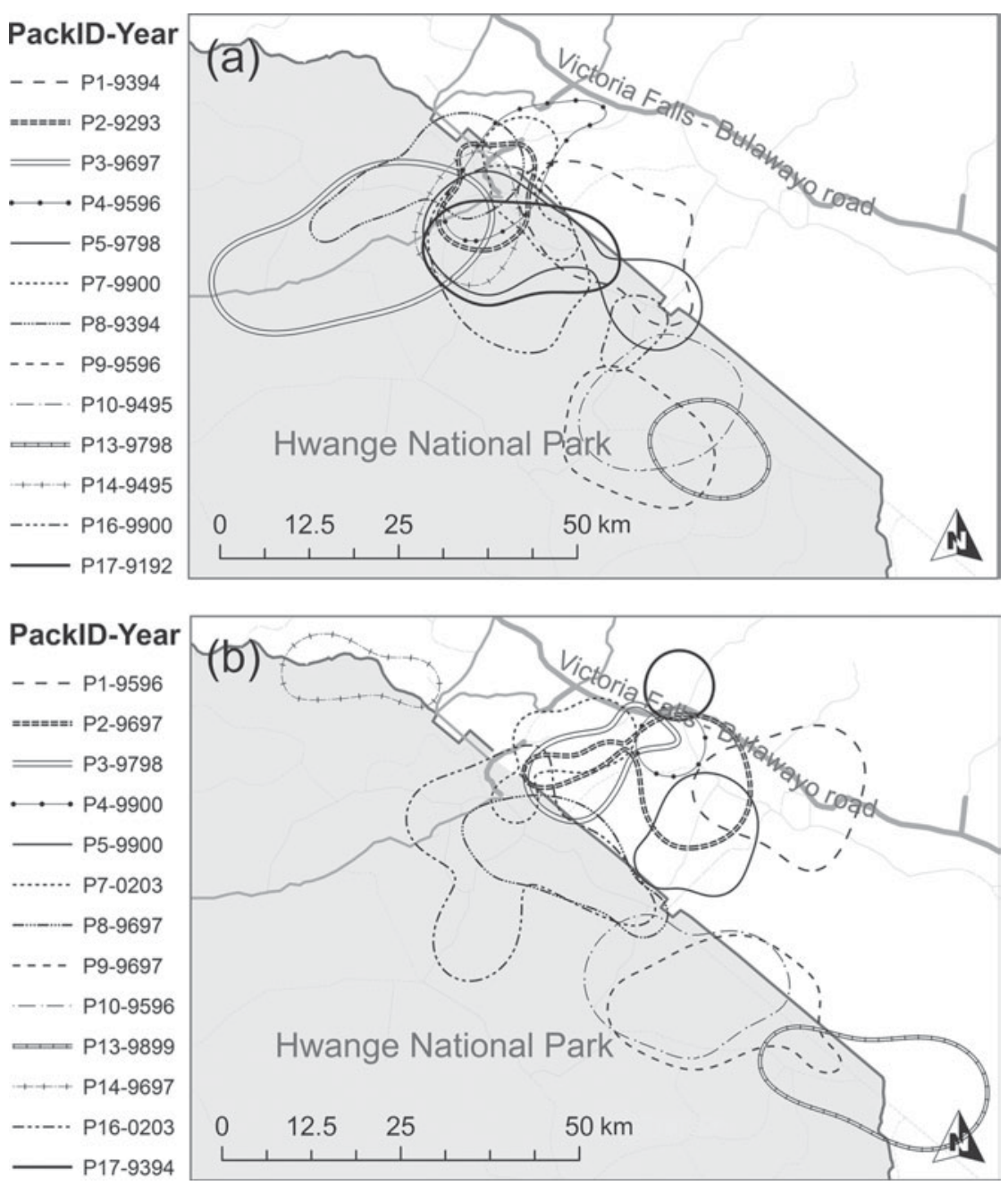

Fig. 2 Movement of the core area (50\% kernel) of the territories of 13 African wild dog Lycaon pictus packs $\left(\mathrm{P}_{1-5}, \mathrm{P}_{7}-10,13,14,16,17\right)$ : (a) the core area of the packs at the start of the study period, (b) the core area of the packs at the end of the study period. The last four digits of PackID-Year indicate the year the pack was studied (the first two digits indicate the year starting with the denning season and the last two digits the year ending just before the denning season the following year; e.g. 9394 is 1993-1994). Note that overlaps are not real but arise from the fact that packs were observed during different years. outside the Park, mean values for pack size at the start of a reproductive year and at the end of a reproductive year, litter size, mortality, dispersal and immigration were calculated for packs with a territory strictly inside the Park, territories that extend both inside and outside the Park, and territories strictly in the buffer zone outside the Park.

To illustrate the movement of African wild dog territories over the years, a fixed kernel method using least square cross validation (Seaman \& Powell, 1996) was used to draw isopleths of the $50 \%$ core areas, using the Home Range Tools extension (Rodgers et al., 2007). Of the 15 study packs, one was extirpated and one disbanded within their first year, therefore we illustrate the movement of territories of only 13 of the 15 study packs.

\section{Analysis of mortality data}

Mortality data were analysed by displaying the frequencies in a contingency table, using Pearson's $\chi^{2}$ tests to see whether there was a significant relationship between inside or outside the Park, and human-caused or natural mortality.
All statistical analyses were performed with SPSS v. 16.0 (SPSS, Chicago, USA).

\section{Results}

\section{Study packs}

Over time the African wild dog packs moved the centroids of their territories closer to or over the Hwange National Park border $\left(F_{4-29}=12.18, \mathrm{P}<0.001\right.$; Fig. 2$)$. For an overview of values for succeeding years see Table 1 . This movement was unidirectional; once a pack moved outside the Park it did not move back inside.

Pack size at the start of a reproductive year was affected by distance of the territory centroid to the Park border $\left(F_{1-41}=5.53, \mathrm{P}=0.024\right)$, with an increase in pack size with the movement of the centroid into the buffer zone outside the Park (regression coefficient $B=-0.12 \pm$ SE 0.05). Pack size at the end of a reproductive year was not affected by distance to the border $(\mathrm{P}>0.05)$. The number of pups born within a litter was affected by distance of the territory 
centroid from the Park border $\left(F_{1-29}=11.04, \mathrm{P}=0.002\right)$, and pack size at the start of a reproductive year $\left(F_{1-33}=14.70\right.$, $\mathrm{P}=0.001)$. Litter size increased with movement of the centroid into the buffer zone outside the Park $(B=-0.17 \pm$ SE 0.05), and an increase in pack size $(B=0.58 \pm \mathrm{SE} 0.15)$. Dispersal and immigration within a pack was not affected by the distance of the territory centroid to the Park border $(\mathrm{P}>0.05)$. The distance of the territory centroids to the Park border affected overall mortality $\left(F_{1-30}=5.88, \mathrm{P}=0.022\right)$, mortality caused by humans $\left(F_{1-45}=21.71, \mathrm{P}<0.001\right)$ and mortality caused by natural circumstances $\left(F_{1-45}=4.38, \mathrm{P}=0.042\right)$ but not mortality caused by unknown circumstances $(\mathrm{P}>0.05)$. Overall mortality increased with the movement of the centroid into the buffer zone $(B=-0.74 \pm \mathrm{SE} 0.30)$, as did mortality caused by humans $(B=-1.16 \pm$ SE 0.25$)$. Mortality caused by natural circumstances decreased with the movement of the centroid into the buffer zone $(B=0.54 \pm$ SE 0.26$)$. The distance of the territory centroid to the Park border affected both direct $\left(F_{1-44}=8.79\right.$, $\mathrm{P}=0.005)$ and indirect $\left(F_{1-45}=8.88, \mathrm{P}=0.005\right)$ humancaused mortality, with an increase in direct $(B=-0.53 \pm \mathrm{SE} 0.18) \quad$ and indirect $\quad(B=-0.72 \pm 0.24)$ human-caused mortality with the movement of the centroid into the buffer zone.

Territory size was affected by distance of the territory centroid to the Park border $\left(F_{1-43}=11.89, \mathrm{P}=0.001\right)$, with a decrease in territory size with the movement of the centroid into the buffer zone $(B=21.84 \pm \mathrm{SE} 6.33)$. A similar result was found for the core area used $\left(F_{1-43}=10.84, \mathrm{P}=0.002\right)$, showing a decrease with movement of the centroid outside the Park $(B=5.99 \pm S E 1.82)$. Mean territory size for packs with a territory centroid inside the Park was $1,243.13 \pm S E 103.76 \mathrm{~km}^{2}$, which was significantly larger than the $809.64 \pm S E 86.69 \mathrm{~km}^{2}$ for packs with a territory centroid outside the Park $\left(t_{(42)}=3.21, \mathrm{P}=0.003\right)$. There was also a significant difference in the size of the core area for packs with a territory centroid inside and outside the Park $\left(t_{(42)}=2.96, \mathrm{P}=0.005\right)$ : the core area for packs with a centroid inside the Park was $308.50 \pm$ SE $30.25 \mathrm{~km}^{2}$; for packs with a centroid in the buffer zone it was $192.53 \pm$ SE $24.82 \mathrm{~km}^{2}$.

Based on the mean values for packs with a territory strictly inside the Park, covering both land inside and outside the Park, or strictly outside the Park, it was found that even though pack size at the start of a reproductive year and the number of pups born outside the Park was higher, the overall mortality of African wild dogs was so high that there was effectively no recruitment and packs fell apart in groups below the minimal pack size of six individuals, necessary for optimal reproduction (Courchamp \& Macdonald, 2001; Rasmussen et al., 2008; Table 2). Eleven of the 15 study packs were extirpated, with seven extirpations confirmed to have been caused by anthropogenic mortality.
TABLE 1 Outcome of the linear mixed model for the distance from the centroid of African wild dog Lycaon pictus territories to the Hwange National Park (Fig. 1) border over succeeding years, showing that over time the centroids moved closer to or over the border.

\begin{tabular}{|c|c|c|c|c|c|}
\hline & $B$ & SE & df & $t$ & $\mathrm{P}$ \\
\hline Intercept & -11.22 & 3.88 & 43.94 & -2.90 & 0.006 \\
\hline \multicolumn{6}{|c|}{ Year (Year 5 used as a reference) } \\
\hline Year 1 & 17.28 & 3.47 & 29.12 & 4.99 & 0.000 \\
\hline Year 2 & 11.73 & 3.47 & 28.95 & 3.38 & 0.002 \\
\hline Year 3 & 7.41 & 3.52 & 28.75 & 2.11 & 0.044 \\
\hline Year 4 & 5.92 & 3.67 & 28.50 & 1.61 & 0.118 \\
\hline
\end{tabular}

\section{Mortality data}

From 1989 to 2010, 327 African wild dogs were reported dead. The majority (71.6\%) of these deaths occurred in the buffer zone outside the Park, with a ratio of 1 dead individual inside the Park to 2.5 dead individuals outside the Park. Humans directly caused $61.8 \%$ of the reported deaths and $73.3 \%$ of the deaths if cascading effects were accounted for (i.e. pups and yearlings that died of starvation because adults were killed by humans; Table 3). Most (67.9\%) anthropogenic causes of mortality were indirect, such as snares and road kills. Direct human-caused mortality (i.e. animals being shot) occurred between 1991 and 2000. After 2000 all cases of anthropogenic mortality were indirect.

There was a significant association between inside or outside the Park and whether or not mortality was caused by human or natural circumstances $\left(\chi^{2}=100.99, \mathrm{P}<0.001\right)$. Based on the odds ratio, the odds of mortality caused by humans were 46.71 times higher outside the Park.

\section{Recent observations}

Although detailed information about pack sizes and territory movement was mainly collected between 1989 and 2002, individual observations show that the problem still exists. In 2009 and $2010>3,000$ snares were collected in the buffer zone around Hwange National Park (Blinston et al., 2010). In August 2009 a pack of seven African wild dogs was released inside the Park in an area without resident packs. The pack moved out of the Park and within $<_{3}$ months was extirpated; two African wild dogs were killed on the main road, two were killed by snares, one dispersed, one individual was never seen again and was presumed dead, and one individual was recaptured.

In October 2006 a pack of 11 African wild dogs was released from the Painted Dog Conservation facilities. The pack established a territory outside Hwange National Park but within 3 months the first individuals were killed by snares. Of the 11 released, five died in snares, one individual was seriously injured by a snare and had to be recaptured, 
TABLE 2 Mean recruitment $( \pm$ SE) of African wild dogs per reproductive year in relation to placement of territory inside $(n=18)$ Hwange National Park (Fig. 1), at the border $(n=33)$, or outside the Park $(n=13)$, and overall.

\begin{tabular}{|c|c|c|c|c|}
\hline & \multicolumn{3}{|c|}{ Location of territory } & \multirow[b]{2}{*}{ Total } \\
\hline & Inside & Border & Outside & \\
\hline Pack size at start & $4.50 \pm 0.63$ & $6.63 \pm 0.54$ & $6.00 \pm 1.23$ & $5.92 \pm 0.42$ \\
\hline Pups born & $5.69 \pm 0.56$ & $6.22 \pm 0.68$ & $7.83 \pm 1.77$ & $5.51 \pm 0.56$ \\
\hline \multicolumn{5}{|l|}{ Mortality of pups } \\
\hline Total & $3.08 \pm 0.51$ & $3.58 \pm 0.45$ & $5.36 \pm 1.33$ & $3.87 \pm 0.42$ \\
\hline Human & $0.17 \pm 0.17$ & $0.96 \pm 0.34$ & $3.00 \pm 1.13$ & $1.23 \pm 0.34$ \\
\hline Natural & $1.83 \pm 0.65$ & $1.29 \pm 0.30$ & $0.82 \pm 0.38$ & $1.32 \pm 0.24$ \\
\hline Unknown & $1.08 \pm 0.48$ & $1.33 \pm 0.33$ & $1.55 \pm 1.01$ & $1.32 \pm 0.31$ \\
\hline \multicolumn{5}{|c|}{ Mortality of adults \& yearlings } \\
\hline Total & $0.50 \pm 0.17$ & $1.60 \pm 0.32$ & $2.54 \pm 0.87$ & $1.49 \pm 0.26$ \\
\hline Human & $0.00 \pm 0.00$ & $1.23 \pm 0.32$ & $2.08 \pm 0.90$ & $1.06 \pm 0.26$ \\
\hline Natural & $0.22 \pm 0.13$ & $0.17 \pm 0.07$ & $0.15 \pm 0.10$ & $0.18 \pm 0.06$ \\
\hline Unknown & $0.28 \pm 0.14$ & $0.20 \pm 0.10$ & $0.31 \pm 0.18$ & $0.24 \pm 0.07$ \\
\hline Immigration & $0.00 \pm 0.00$ & $0.37 \pm 0.23$ & $0.23 \pm 0.12$ & $0.24 \pm 0.12$ \\
\hline Dispersal & $0.50 \pm 0.29$ & $1.14 \pm 0.30$ & $2.00 \pm 1.12$ & $1.14 \pm 0.29$ \\
\hline Pack size at end & $5.44 \pm 0.90$ & $6.43 \pm 0.62$ & $4.15 \pm 1.21$ & $5.71 \pm 0.48$ \\
\hline Recruitment & $0.94 \pm 0.50$ & $-0.27 \pm 0.63$ & $-1.85 \pm 1.38$ & $-0.25 \pm 0.46$ \\
\hline
\end{tabular}

TABLE 3 Causes of mortality (expressed as a percentage) of African wild dogs from 1989 to 2010 inside and outside Hwange National Park (Fig. 1).

\begin{tabular}{lcc}
\hline & Inside, \% (n) & Outside (\%) \\
\hline Human causes & $0.0(0)$ & $25.6(60)$ \\
Snare & $5.4(5)$ & $12.0(28)$ \\
Road traffic & $0.0(0)$ & $18.8(44)$ \\
Shooting & & \\
Natural causes & $17.2(16)$ & $3.9(9)$ \\
Lions and hyaenas & $12.9(19)$ & $11.5(27)$ \\
Starvation & $20.4(19)$ & $18.8(23)$ \\
Natural other & $44.1(41)$ & $71.6(234)$ \\
Unknown causes & $28.4(93)$ & \\
Total & &
\end{tabular}

two individuals were killed by lions, two of the remaining three died for unknown reasons, and one remaining individual was recaptured.

\section{Discussion}

Although African wild dogs experienced a high level of anthropogenic mortality outside Hwange National Park, they moved their territories closer to, or over, the Park border. In a classic source-sink system, movement of animals into the sink is density dependent; i.e. surplus animals from the high-quality source habitat are forced to migrate into the low-quality sink habitat because there is not enough source habitat available (Pulliam, 1988; Pulliam \& Danielson, 1991; Dias, 1996). Although the rate of migration could increase because of a vacuum effect, the movement of animals remains density dependent; animals move into the sink because lower population densities within the sink habitat reduce competition. However, the movement of African wild dogs into the buffer zone is unlikely to be density dependent because initially packs established territories inside the Park, and population densities were low both inside and outside the Park. The fact that territory sizes outside the Park were smaller than those inside the Park supports this theory, as generally territory sizes and population densities are negatively related (Marker \& Dickman, 2005; Loveridge et al., 2009a; Schradin et al., 2010).

Territory sizes have also been found to be negatively related to prey density (Marker \& Dickman, 2005; Loveridge et al., 2009b) and are seen as an indication of resource distribution (Grant et al., 1992). The smaller territories outside Hwange National Park could therefore be interpreted as an indication of higher prey abundance. Densities of kudu and impala were similar inside and outside the Park, but duiker densities were higher outside the Park (Van der Meer et al., 2013). However, foraging distance (the distance at which a pack first encounters prey), the number of hunt periods per day and diet composition did not differ inside and outside the Park (Van der Meer et al., 2013), and it therefore seems unlikely that differences in duiker abundance explain the observed differences in sizes of territories and core areas.

African wild dogs often coexist with lions and spotted hyaenas, which are known to affect African wild dogs by interspecific killing (Reich, 1981; Woodroffe et al., 1997) and kleptoparasitism (Reich, 1981; Creel, 2001; Gorman et al., 1998). The risk of African wild dogs encountering lions and 
spotted hyaenas was significantly higher inside compared to outside Hwange National Park (Van der Meer et al., 2011). This could explain why natural mortality decreased with an increase in distance of the territory centroid into the buffer zone outside the Park. African wild dogs have been found to move significantly longer distances after a kill when lions and spotted hyaenas are present (Rasmussen, 2009). With a lower level of competition with lions and spotted hyaenas in the buffer zone (Van der Meer et al., 2011) African wild dogs possibly travelled less extensively to avoid them, which could have contributed to smaller territory sizes outside the Park.

As well as a higher hunting success and less competition with lions and hyaenas, African wild dogs outside Hwange National Park have been found to have better access to suitable den sites (Van der Meer, 2011). With an increase in litter size with the movement of the territory centroid outside the Park, it seems that the buffer zone serves as an ecological trap, where fitness-enhancing favourable ecological conditions attract African wild dogs unable to perceive the higher mortality risk posed by humans. The fact that the movement of African wild dog territories is unlikely to be density dependent supports this theory.

Ecological traps occur when sudden natural or humaninduced changes cause formerly reliable ecological cues to be no longer associated with an adaptive outcome, causing animals to make a maladaptive choice for a habitat in which their reproductive success or adult survival is diminished (Kolbe \& Janzen, 2002; Kristan, 2003). Studies on animals that experience direct anthropogenic mortality through shooting have shown that it is possible for animals to perceive and respond to direct human-caused mortality by changing their spatial distribution and/or temporal activity pattern (Kilgo et al., 1998; Swenson, 1999; Tolon et al., 2009; Rasmussen \& Macdonald, 2012). With most of the anthropogenic causes of mortality in this study being indirect, it is unlikely that African wild dogs could adequately perceive and respond to the higher anthropogenic mortality risk in the buffer zone.

Within an ecological trap the sink population can only be temporarily sustained by the source population before resulting in an overall population decline (Kristan, 2003). Since 1997 the African wild dog population in and around Hwange National Park has been reduced by $>50 \%$ (Rasmussen, 1997; Woodroffe et al., 1997; Zimbabwe Parks \& Wildlife Management Authority, 2009), indicating that the source population no longer supports the sink population. This decline is likely to be accelerated by the positive relationship between pack size and reproduction; once the number of pack members drops below a critical size reproduction decreases (Courchamp \& Macdonald, 2001; Rasmussen et al., 2008; Gusset \& Macdonald 2010). Landscapes that, viewed in a source-sink framework, would be expected to support a stable population may instead lead to extirpation of a population, if sinks are actually traps (Delibes et al., 2001; Kokko \& Sutherland, 2001; Gilroy \& Sutherland, 2007). To ensure adequate conservation of a species it is important to define whether a system serves as a classic source-sink system, where resources are most efficiently used by conserving high-quality habitat to maintain the source population, or whether a system serves as an ecological trap, where conservation efforts should focus on reducing the attractiveness or increasing the quality of the low-quality habitat to prevent rapid extirpation of the species.

To prevent extirpation of African wild dogs in and around Hwange National Park conventional fencing (Gusset et al., 2008) or bio-fencing using scent mark deployment (Jackson et al., 2012) could be considered. Although both types of fencing have been successfully used to restrict the ranging behaviour of African wild dogs (Gusset et al., 2008; Jackson et al., 2012) it comes at considerable ecological costs because it reduces connectivity and obstructs natural dispersal (Somers et al., 2012). Because of favourable ecological conditions, the buffer zone has the potential to be the most productive African wild dog habitat. Increasing the quality of the buffer zone by reducing the level of anthropogenic mortality through the prevention of illegal activities such as poaching, and the promotion of a positive attitude towards African wild dogs, is therefore likely to be the best solution to ensure recovery of the African wild dog population in and around Hwange National Park.

\section{Acknowledgements}

The Zimbabwe Research Council and the Zimbabwe Parks and Wildlife Management Authority are kindly acknowledged for providing the opportunity to carry out this research. In addition we would like to thank the Hwange National Parks and Wildlife Management Authority, the Natural History Museum of Zimbabwe, Forestry Commission, Touch the Wild, The Hide, Hwange Safari Lodge, Lions Den Enterprises, and the various farmers within the Gwaai Intensive Conservation Area for allowing us access to their premises and supporting our fieldwork. We thank Jealous Mpofu for assisting with the field work. We thank Simon Chamaillé-Jammes and Marion Valeix for their comments, and anonymous referees for their critiques. This study was supported by Stichting Painted Dog Conservation and the Painted Dog Conservation project.

\section{References}

Bailey, T.N., Bangs, E.E., Portner, M.F., Malloy, J.C. \& McAvinchey, R.J. (1986) An apparent overexploited lynx population on the Kenai peninsula, Alaska. Journal of Wildlife Management, 50, 279-290. 
Balme, G.A., Slotow, R. \& Hunter, L. (2009) Impact of conservation interventions on the dynamics and persistence of a persecuted leopard (Panthera pardus) population. Biological Conservation, 142, 2681-2690.

B Atтin, J. (2004) When good animals love bad habitats: ecological traps and the conservation of animal populations. Conservation Biology, 18, 1482-1491.

Blinston, P., Rasmussen, G.S.A. \& Van der Meer, E. (2010) Painted Dog Conservation End of the Year Report 2010. PDC, Dete, Zimbabwe.

Courchamp, F. \& Macdonald, D.W. (2001) Crucial importance of pack size in the African wild dog (Lycaon pictus). Animal Conservation, 4, 169-174.

Creel, S. (2001) Four factors modifying the effect of competition on carnivore population dynamics as illustrated by African wild dogs. Conservation Biology, 15, 271-271.

Delibes, M., Gaona, P. \& Ferreras, P. (2001) Effects of an attractive sink leading into maladaptive habitat selection. American Naturalist, 158, 277-285.

DIAs, P.C. (1996) Sources and sinks in population biology. TREE, 11, 326-330.

Gilroy, J.J. \& Sutherland, W.J. (2007) Beyond ecological traps: perceptual errors and undervalued resources. Trends in Ecology and Evolution, 22, 351-356.

Gorman, M.L., Mills, M.G.L., RaAth, J.P. \& Speakman, J.R. (1998) High hunting costs make African wild dog vulnerable to kleptoparasitism by hyenas. Nature, 391, 479-481.

Grant, J.W.A., Chapman, C.A. \& Richardson, K.S. (1992) Defended vs. undefended home range size of carnivores, ungulates and primates. Behavioral Ecology and Sociobiology, 31, 149-161.

Gunther, I. \& Terkel, J. (2002) Regulation of free-roaming cat (Felis silvestris catus) populations: a survey of the literature and its application to Israel. Animal Welfare, 11, 171-188.

Gusset, M. \& Macdonald, D.W. (2010) Group size effects in cooperatively breeding African wild dogs. Animal Behaviour, 79, $425-428$.

Gusset, M., Ryan, S.J., Hofmeyr, M., van Dyk, G., Davies-Mostert, H.T., Graf, J.A. et al. (2008) Efforts going to the dogs? Evaluating attempts to re-introduce endangered wild dogs in South Africa. Journal of Applied Ecology, 45, 100-108.

Gusset, M., Swarner, M.J., Mponwane, L., Keletile, K., \& McNutT, J.W. (2009) Human-wildlife conflict in northern Botswana: livestock predation by Endangered African wild dog Lycaon pictus and other carnivores. Oryx, 43, 67-72.

Inskip, C. \& Zimmermann, A. (2009) Human-felid conflict: a review of patterns and priorities worldwide. Oryx, 43, 18-34.

Jackson, C.R., McNutt, J.W. \& Apps, P.J. (2012) Managing the ranging behaviour of African wild dogs (Lycaon pictus) using translocated scent marks. Wildlife Research, 39, 31-34.

Janmaat, K.R.L., Olupot, W., Chancellor, R.L., Arlet, M.E. \& WASER, P.M. (2009) Long-term site fidelity and individual home range shifts in Lophocebus albigena. International Journal of Primatology, 30, 443-466.

Ji, W., Sarre, S.D., Aitken, N., Hankin, R.K.S. \& Clout, M.N. (2001) Sex-biased dispersal and a density-independent mating system in the Australian brush tail possum, as revealed by minisatellite DNA profiling. Molecular Ecology, 10, 1527-1537.

Kilgo, J.C., Labisky, R.F. \& Fritzen, D.E. (1998) Influences of hunting on the behaviour of white-tailed deer: implications for conservation of the Florida panther. Conservation Biology, $12,1359-1364$.

Koкко, H. \& Sutherland, W.J. (2001) Ecological traps in changing environments: ecological and evolutionary consequences of a behaviourally mediated Allee effect. Evolutionary Ecology Research, 3, 37-551.

Kolbe, J.J. \& Janzen, F.J. (2002) Impact of nest site selection on nest success and nest temperature in natural and disturbed habitats. Ecology, 83, 269-281.

Kristan, W.B. (2003) The role of habitat selection behaviour in population dynamics: source-sink systems and ecological traps. Oikos, 103, 457-468.

Loveridge, A.J., Hamson, G., Davidson, Z. \& Macdonald, D.W. (2009a) Chapter 11: African Lions on the edge: reserve boundaries as 'attractive sinks'. In The Biology and Conservation of Wild Felids (eds D.W. Macdonald \& A.J. Loveridge), pp. 283-304. Oxford University Press, Oxford, UK.

Loveridge, A.J., Searle, A.W., Murindagomo, F. \& Macdonald, D.W. (2007) The impact of sport-hunting on the population dynamics of an African lion population in a protected area. Biological Conservation, 134, 548-558.

Loveridge, A.J.M., Valeix, M., Davidson, Z., Murindagomo, F., Fritz, H. \& Macdonald, D.W. (2009b) Changes in home range size of African lions in relation to pride size and prey biomass in a semi-arid savanna. Ecography, 32, 953-962.

Macdonald, D.W., Riordan, P. \& Mathews, F. (2006) Biological hurdles to the control of TB in cattle: a test of two hypotheses concerning wildlife to explain the failure of control. Biological Conservation, 131, 268-286.

Marker, L.L. \& Dickman, A.J. (2005) Factors affecting leopard (Panthera pardus) spatial ecology, with particular reference to Namibian farmland. South African Journal of Wildlife Research, $35,105-115$.

Mills, M.G.L. \& Gorman, M.L. (1997) Factors affecting the density and distribution of wild dogs in the Kruger National Park. Conservation Biology, 11, 1397-1406.

Peace Parks Foundation (2009) Integrated Development Plan: Zimbabwean Component of the KAZA TFCA. Parks and Wildlife Management Authority, Harare, Zimbabwe.

Pulliam, H.R. (1988) Sources, sinks and population regulation. American Naturalist, 132, 652-661.

Pulliam, H.R. \& Danielson, B.J. (1991) Sources, sinks and habitat selection: a landscape perspective on population dynamics. American Naturalist, 137, S50-S66.

Rasmussen, G.S.A. (1997) Conservation Status of the Painted Hunting Dog Lycaon pictus in Zimbabwe. Zimbabwe Parks and Wildlife Management Authority, Ministry of Environment and Tourism, Harare, Zimbabwe.

Rasmussen, G.S.A. (2009) Anthropogenic factors influencing biological processes of the painted dog Lycaon pictus. $\mathrm{PhD}$ thesis. Oxford University, Oxford, UK.

Rasmussen, G.S.A., Gusset, M., Courchamp, F. \& Macdonald, D.W. (2008) Achilles' heel of sociality revealed by energetic poverty trap in cursorial hunters. The American Naturalist, 172, 508-518.

Rasmussen, G.S.A. \& Macdonald, D.W. (2012) Masking of the zeitgeber: African wild dogs mitigate persecution by balancing time. Journal of Zoology, 286, 232-242.

Reich, A. (1981) The behaviour and ecology of the African wild dog Lycaon pictus in the Kruger National Park. PhD. thesis. Yale University, New Haven, USA.

Rodgers, A.R., Carr, A.P., Beyer, H.L., Smith, L. \& Kie, J.G. (2007) HRT: Home Range Tools for ArcGIS. Http://flash.lakeheadu.ca/ $\sim$ arodgers/hre/ [accessed 28 June 2013].

Robertson, B.A. \& Hutto, R.L. (2006) A framework for understanding ecological traps and an evaluation of existing evidence. Ecology, 87, 1075-1085.

Schlaepfer, M.A., Runge, M.C. \& Sherman, P.W. (2002) Ecological and evolutionary traps. TREE, 17, 474-480. 
Schradin, C., Schmohl, G., Rödel, H.G., Schoepf, I., Treffler, S.M., Brenner, J. et al. (2010) Female home range size is regulated by resource distribution and intraspecific competition: a long-term field study. Animal Behaviour, 79, 195-203.

Seaman, D.E. \& Powell, R.A. (1996) An evaluation of the accuracy of kernel density estimators for home range analysis. Ecology, 77, 2075-2085.

Somers, M.J., Gusset, M. \& Dalerum, F. (2012) Modelling the effect of fences on the viability of spatially structured populations of African wild dogs. In Fencing for Conservation: Restriction of Evolutionary Potential or a Riposte to Threatening Processes? (eds M.J. Somers \& M.W. Hayward), pp. 187-196. Springer, New York, USA.

Swenson, J.E. (1999) Does hunting affect the behavior of brown bears in Eurasia? Ursus, 11, 157-162.

Tolon, V., Dray, S., Loison, A., Zeileis, A., Fischer, C. \& BAUBET, E. (2009) Responding to spatial and temporal variations in predation risk: space use of a game species in a changing landscape of fear. Canadian Journal of Zoology, 87, 1129-1137.

VAN DER MeER, E. (2011) Is the grass greener on the other side? Testing the ecological trap hypothesis for African wild dogs (Lycaon pictus) in and around Hwange National Park, Zimbabwe. PhD thesis. Lyon University, Lyon, France.

Van der Meer, E., Moyo, M., Rasmussen, G.S.A. \& Fritz, H. (2011) An empirical and experimental test of risk and costs of kleptoparasitism for African wild dogs (Lycaon pictus) inside and outside a protected area. Behavioral Ecology, 22, 985-992.

Van der Meer, E., Rasmussen, G.S.A., Muvengwi, J. \& FrITZ, H. (2013) Foraging costs, hunting success and its implications for African wild dog (Lycaon pictus) conservation inside and outside a protected area. African Journal of Ecology, doi 10.1111/aje.12092.

Woodroffe, R. (2000) Predators and people: using human densities to interpret declines of large carnivores. Animal Conservation, 3 , $165-173$.

Woodroffe, R. \& Ginsberg, J.R. (1998) Edge effects and the extinction of populations inside protected areas. Science, 280, $2126-2128$
Woodroffe, R., Ginsberg, J.R. \& Macdonald, D. (1997) The African Wild Dog-Status Survey and Conservation Action Plan. IUCN/Species Survival Commission Canid Specialist Group. Http:// www.canids.org/PUBLICAT/AWDACTPL/african_wild_dog_AP. pdf [accessed 28 June 2013].

Woodroffe, R., Davies-Mostert, H., Ginsberg, J., Graf, J., Leigh, K., MCCreery, K. et al. (2007) Rates and causes of mortality in Endangered African wild dogs Lycaon pictus: lessons for management and monitoring. Oryx, 41, 215-223.

Woodroffe, R., McNutt, J.W. \& Mills, M.G.L. (2004) African wild dog (Lycaon pictus). In Canids: Foxes, Wolves, Jackals and Dogs 2004 Status Survey and Conservation Action Plan (eds C. Sillero-Zubiri, M. Hoffmann \& D.W. Macdonald), pp. 174-183. IUCN/Species Survival Commission Canid Specialist Group, Geneva, Switzerland. Http://www.canids.org/cap/index.htm [accessed 28 June 2013].

Woodroffe, R. \& Sillero-Zubiri, C. (2012) Lycaon pictus. In IUCN Red List of Threatened Species v. 2012.2. Http://www.iucnredlist.org [accessed 25 June 2013].

Zimbabwe Parks \& Wildife Management Authority (2009) National Conservation Action Plan for Cheetahs and African Wild Dogs in Zimbabwe. Zimbabwe Parks and Wildlife Management Authority, Harare, Zimbabwe.

\section{Biographical sketches}

Esther VAN Der Meer is founder and director of Cheetah Conservation Project Zimbabwe. Her research interests are in conservation ecology, carnivore interactions and predator-prey interactions. HERVE FRITZ is founder and director of the Hwange Environmental Research Development project. His research focuses on large herbivore ecology, predator-prey interactions and the influence of human activities and land use on biodiversity. PETER BLINSTON is managing director of the Painted Dog Conservation project and helps translate vision and research into effective conservation programmes. Gregory Rasmussen is founder and research director of the Painted Dog Conservation project and a member of the IUCN/Species Survival Commission Canid Specialist Group. For more than 20 years he has been conducting research on African wild dog ecology in relation to the conservation of the species. 